Gut, 1973, 14, 1-12

\title{
Ultrastructural changes suggestive of immune reactions in the jejunal mucosa of coeliac children following gluten challenge
}

\author{
MARGOT SHINER ${ }^{1}$ \\ From the Medical Research Council, Gastroenterology Unit, Central Middlesex Hospital, London
}

SUMMARY The jejunal mucosa of eight coeliac children on a gluten-free diet and two non-coeliac children was studied by light and electron microscopy two to 98 hours after a single challenge dose of gluten.

In all coeliac patients the early cytopathological reactions were principally confined to the structures within the subepithelial connective tissue. Changes were observed in the connective tissue fibrils, the basement membranes of epithelial and endothelial cells, the endothelium of small blood vessels, and the type and degree of inflammatory cell infiltration. The timing of these reactions was compatible with the concept that gluten acts as an antigen and combines with antibody in the form of immune complexes in the connective tissue close to the epithelium and to small blood vessels. These changes appeared to precede epithelial cell damage.

No subepithelial tissue changes were seen in the non-coeliac patients after gluten challenge.

Despite considerable interest and intensive research during the past 25 years, the aetiology of coeliac disease remains unknown. Assuming that gluten intolerance is one of the aetiological factors, two main hypotheses for the deleterious action have been advanced. The first concerns a possible deficiency of proteolytic enzymes within the absorbing epithelium which would lead to an inability to break down gluten but the recent work of several investigators (Messer, Anderson, and Townley, 1961; Dolly and Fottrell, 1969; Douglas and Booth, 1970) has failed to show any evidence of a primary enzyme deficiency. The second, gaining in popularity, is concerned with immunological effects of gluten in the small bowel mucosa and its more widespread effect on the lymphoreticular system. Circulating antibodies to gluten (Taylor, Truelove, and Wright, 1964; Kenrick and Walker-Smith, 1970), elevated serum levels of IgM (Hobbs and Hepner, 1968; Kenrick and WalkerSmith, 1970), and impaired lymphocyte transformation (Blecher, Brzechwa-Ajdukiewicz, McCarthy, and Read, 1969) have been reported. Within the small bowel, precipitins to gluten fraction III have been reported in the jejunal juice of untreated patients (Katz, Kantor, and Herskovic, 1968). The

${ }^{1}$ Member of scientific staff.

Received for publication 2 October 1972. jejunal mucosa in coeliac patients has been reported to contain more IgM- and fewer IgA-producing immunocytes (Douglas, Crabbé, and Hobbs, 1970) than in control subjects. Immunofluorescence studies with the use of specific antibodies to gluten have shown positive staining of mucosal immunocytes (Rubin, Fauci, Sleisenger, and Jeffries, 1965). All these investigations suggest that there may be an immunological reaction to gluten but do not indicate in what way the antigenic properties of the protein affect the pathogenesis of coeliac disease.

Shmerling and Shiner (1970) have reported an ultrastructural investigation of two coeliac children treated with a gluten-free diet for a number of years. Serial jejunal biopsies following a challenging dose of gluten revealed early morphological changes, principally in the subepithelial connective tissue layers. These involved the basement membrane or basement lamina of the epithelial and endothelial cells, the endothelium of small blood vessels, the connective tissue fibrils, and the infiltrating inflammatory cells. In this paper the preliminary investigations were extended to eight coeliac and two non-coeliac patients. The findings, based on ultrastructural changes two to 98 hours following gluten, suggest that in coeliac disease changes occur which are compatible with an immunopathological reaction. 


\section{Material and Methods}

The eight coeliac patients comprised six females and two males, their ages ranging from 12 months to 8 years 10 months (Table I). In every child the diagnosis was established on clinical, biochemical, and histological criteria and each had been treated with a gluten-free diet for periods varying between six months and five and a half years. Only three patients $(1,2$, and 3$)$ had kept the diet strictly though all eight were clinically well and did not suffer from diarrhoea.

Of the two non-coeliac patients, one (patient 9) has been reported in detail in a comparative study with a coeliac patient (Shiner and Shmerling, 1972). The other (patient 10) was a boy who came under investigation for diarrhoea at the age of 18 months. No definite diagnosis was made at that time but malabsorption was ruled out by faecal fat estimations and glucose and xylose absorption studies. A jejunal biopsy was unsuccessful. Nevertheless he was started on a gluten-free diet and since he showed some signs of improvement he continued with this diet for the next three years. On his present re-admission and investigation at the age of $4 \frac{1}{2}$ years, his dietary treatment was re-assessed. Again, no evidence of malabsorption was found and the gluten-free diet was discontinued. The patient has remained in good health and on an ordinary diet for the past 12 months.

Jejunal biopsies with a Crosby capsule were performed in all patients after a fast of 12 to 18 hours. All were subjected to an initial jejunal biopsy. This was followed by oral or intraduodenal administration of a single dose of 7 to $20 \mathrm{~g}$ gluten prepared as a suspension in $100 \mathrm{ml}$ of water and boiled for 20 minutes. From one to three repeat biopsies taken two to 98 hours after gluten administration were performed in each patient. All initial and repeat biopsies were examined with a stereo, light, and electron microscope. The methods of fixing, embedding, and sectioning of the biopsy material for electron microscopy have been described elsewhere (Shiner, 1967). Double fixation with 3\% glutaraldehyde-cacodylate and $1 \%$ osmium tetroxide was used followed by dehydration in graded alcohol and embedding in epon (epoxy resin 812). Serial thick and thin sections were cut on an ultramicrotome; the former were stained with $1 \%$ toluidine blue and examined with the light microscope for orientation and morphological identification of the area to be studied in the thin sections with the electron microscope.

\section{Results}

\section{LIGHT MICROSCOPY}

On stereomicroscopic examination of the initial biopsies of the eight coeliac patients only three (patients 1,2, and 3) showed normal finger-shaped villi (Table II). Two patients (4 and 5) had fingers as well as broad, tongue-shaped villi or early convolutions and three (patients 6,7, and 8) had tongues and early convolutions.

Histological examination of these initial biopsies confirmed the stereomicroscopic appearances, showing a normal mucosa in the first three patients, a mild partial villous atrophy in the next two, and a more severe partial villous atrophy in the last three patients. Inflammatory cells, mainly lymphocytes and plasma cells, appeared to be increased in numbers in the patients with partial villous atrophy.

The stereomicroscopic and histological appearances of the initial biopsies on the two non-coeliac patients were within normal limits.

The initial biopsies were compared with each patient's own repeat biopsy or biopsies obtained after gluten loading. No definite changes were found on stereomicroscopic examination, except for occasional

\begin{tabular}{|c|c|c|c|c|c|c|c|}
\hline Patient & Sex & $\begin{array}{l}\text { Age } \\
(y r)\end{array}$ & Disease & $\begin{array}{l}\text { Treatment with } \\
\text { Gluten-free Diet } \\
(y r)\end{array}$ & $\begin{array}{l}\text { Dose of Gluten } \\
(\mathrm{g})\end{array}$ & Route & $\begin{array}{l}\text { Time of Repeat } \\
\text { Biopsy }(h r)\end{array}$ \\
\hline $\begin{array}{r}1 \\
2 \\
3 \\
4 \\
4 \\
5 \\
6 \\
7 \\
8 \\
9 \\
9\end{array}$ & $\begin{array}{l}\mathbf{M} \\
\mathbf{F} \\
\mathbf{F} \\
\mathbf{M} \\
\mathbf{F} \\
\mathbf{F} \\
\mathbf{F} \\
\mathbf{F} \\
\mathbf{F} \\
\mathbf{M}\end{array}$ & $\begin{array}{lr}8 & 10 / 12 \\
4 & \\
3 & 6 / 12 \\
2 & 7 / 12 \\
& 20 / 12 \\
5 & 7 / 12 \\
1 & \\
4 & 3 / 12 \\
& 6 / 12 \\
4 & 6 / 12\end{array}$ & $\begin{array}{r}\text { CD } \\
C D \\
C D \\
C D \\
C D \\
C D \\
C D \\
C D \\
\text { Non-CD } \\
\text { Non-CD }\end{array}$ & $\begin{array}{r}51 \\
2 \\
21 \\
9 / 12 \\
11 / 12 \\
3 \\
6 / 12 \\
3 \\
\frac{3}{3}\end{array}$ & $\begin{array}{r}20 \\
20 \\
20 \\
20 \\
10,10 \\
7 \\
20 \\
20 \\
20 \\
20\end{array}$ & $\begin{array}{l}\text { ID } \\
\text { ID } \\
\text { ID } \\
\text { Oral } \\
\text { Oral } \\
\text { ID } \\
\text { Oral } \\
\text { Oral } \\
\text { Oral } \\
\text { Oral }\end{array}$ & $\begin{array}{l}(0), 2,50,98 \\
(0), 2,72 \\
(0), 5,24 \\
(0), 21 \\
(0), 48 \\
(0), 2,48,96 \\
(0), 21,24 \\
(0), 17 \\
(0), 24 \\
(0), 28\end{array}$ \\
\hline
\end{tabular}

Table I Clinical data and method of investigation of the eight coeliac and two non-coeliac patients

CD = coeliac disease

(0) = initial (pre-gluten) biopsy

ID $=$ intraduodenal 


\begin{tabular}{|c|c|c|c|c|c|c|c|c|}
\hline \multirow[t]{2}{*}{ Patient } & \multirow[t]{2}{*}{ Disease } & \multicolumn{2}{|l|}{ Initial Biopsy } & \multicolumn{5}{|c|}{ Repeat Biopsies after Gluten } \\
\hline & & $\begin{array}{l}\text { Stereomicroscopic } \\
\text { Appearances }\end{array}$ & Histology & $\begin{array}{l}\text { Time } \\
(\mathrm{hr})\end{array}$ & $\begin{array}{l}\text { Stereomicroscopic } \\
\text { Appearances }\end{array}$ & $\begin{array}{l}\text { Epithelial } \\
\text { Cell Loss }\end{array}$ & $\begin{array}{l}\text { Widening of } \\
\text { Connective } \\
\text { Tissue Spaces }\end{array}$ & $\begin{array}{l}\text { Increased } \\
\text { Cell } \\
\text { Infiltration }\end{array}$ \\
\hline 1 & Coeliac & Fingers & Normal & $\begin{array}{r}2 \\
50 \\
98\end{array}$ & $\begin{array}{l}\text { No change } \\
\text { No change } \\
\text { No change }\end{array}$ & $\begin{array}{l}0 \\
0 \\
0\end{array}$ & $\begin{array}{l}\mathbf{0} \\
\mathbf{0} \\
+\end{array}$ & $\begin{array}{l}0 \\
0 \\
+\end{array}$ \\
\hline 2 & Coeliac & Fingers & Normal & $7^{2}$ & $\begin{array}{l}\text { No change } \\
\text { No change }\end{array}$ & $\begin{array}{l}\mathbf{0} \\
\mathbf{0}\end{array}$ & $\begin{array}{l}0 \\
\pm\end{array}$ & $\begin{array}{l}0 \\
+\end{array}$ \\
\hline 3 & Coeliac & Fingers, some leaves & Normal & $\begin{array}{r}5 \\
24\end{array}$ & $\begin{array}{l}\text { Swelling } \\
\text { Slight swelling }\end{array}$ & $\begin{array}{l}\mathbf{0} \\
\mathbf{0}\end{array}$ & $\begin{array}{l}+ \\
+ \\
\pm\end{array}$ & $\begin{array}{l}0 \\
0\end{array}$ \\
\hline 4 & Coeliac & $\begin{array}{l}\text { Fingers, leaves, } \\
\text { early convolutions }\end{array}$ & $\begin{array}{l}\text { Normal to partial } \\
\text { villous atrophy }\end{array}$ & 21 & Swelling & 0 & + & \pm \\
\hline 5 & Coeliac & $\begin{array}{l}\text { Fingers, leaves, } \\
\text { early convolutions }\end{array}$ & $\begin{array}{l}\text { Normal to partial } \\
\text { villous atrophy }\end{array}$ & 48 & No change & + & + & + \\
\hline 6 & Coeliac & $\begin{array}{l}\text { Broad leaves, } \\
\text { early convolutions }\end{array}$ & $\begin{array}{l}\text { Partial villous } \\
\text { atrophy }\end{array}$ & $\begin{array}{r}2 \\
48 \\
96\end{array}$ & $\begin{array}{l}\text { No change } \\
\text { Swelling } \\
\text { Slight swelling }\end{array}$ & $\begin{array}{l}0 \\
0 \\
+\end{array}$ & $\begin{array}{l}0 \\
+ \\
+\end{array}$ & $\begin{array}{l}0 \\
+ \\
+\end{array}$ \\
\hline 7 & Coeliac & $\begin{array}{l}\text { Leaves and } \\
\text { convolutions }\end{array}$ & $\begin{array}{l}\text { Partial villous } \\
\text { atrophy }\end{array}$ & $\begin{array}{l}21 \\
24\end{array}$ & $\begin{array}{l}\text { No change } \\
\text { No change }\end{array}$ & $\begin{array}{l}0 \\
0\end{array}$ & $\begin{array}{l}+ \\
+\end{array}$ & $\begin{array}{l}+ \\
+\end{array}$ \\
\hline 8 & Coeliac & $\begin{array}{l}\text { Tongues and } \\
\text { convolutions }\end{array}$ & $\begin{array}{l}\text { Partial villous } \\
\text { atrophy }\end{array}$ & 17 & No change & $\mathbf{0}$ & \pm & + \\
\hline 9 & $\begin{array}{l}\text { Non- } \\
\text { coeliac }\end{array}$ & $\begin{array}{l}\text { Mainly fingers, some } \\
\text { broad leaves }\end{array}$ & Normal & 24 & No change & 0 & $\mathbf{0}$ & 0 \\
\hline 10 & $\begin{array}{l}\text { Non- } \\
\text { coeliac }\end{array}$ & $\begin{array}{l}\text { Mainly fingers, some } \\
\text { leaves }\end{array}$ & Normal & 28 & Slight swelling & 0 & 0 & 0 \\
\hline
\end{tabular}

Table II Histological data of initial and post-gluten biopsies of eight coeliac and two non-coeliac patients $\pm=$ slight increase

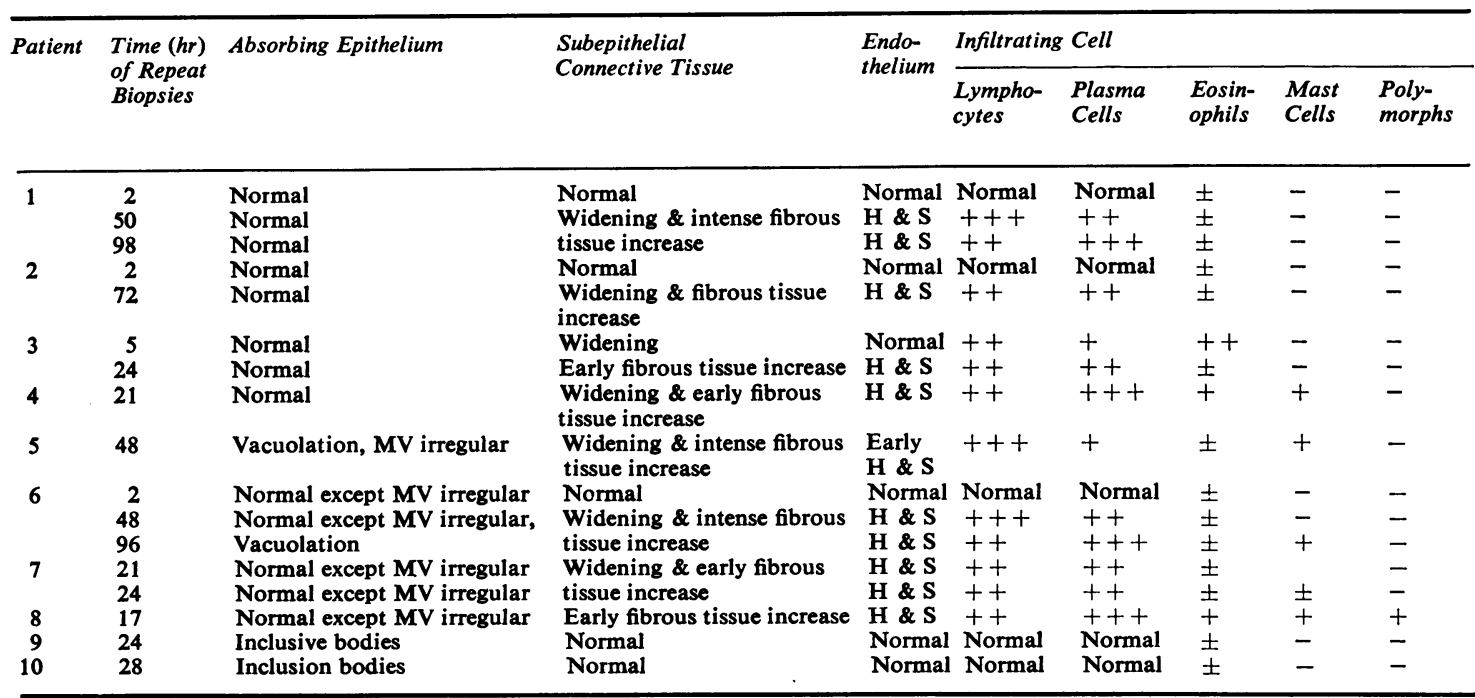

Table III Ultrastructural changes observed in the jejunal mucosa after gluten challenge

MV = microvilli

$$
\begin{aligned}
\pm & =\text { slight increase } \\
+-+++ & =\text { moderate to large increase }
\end{aligned}
$$

$\mathbf{H}=$ hypertrophy of endothelial $\mathbf{S}=$ swelling $\}$ cells mucosal swelling noted in the coeliac and the noncoeliac patients. Histological comparison of preand post-gluten biopsies again showed only minor changes, such as increased epithelial cell loss (patients 5 and 6), widening of the connective tissue spaces, or an increase in inflammatory cells. In one of the two non-coeliac patients (patient 9) vacuolation in the absorbing villous epithelium was seen.

\section{ELECTRON MICROSCOPY}

The villous absorbing cells

The ultrastructural appearances of the villous absorbing cells are summarized in Table III. In the pre-gluten biopsies the absorbing cells of four of the eight coeliac patients appeared normal (Fig. 1) and in the other four irregularity of the microvilli was the 
only abnormality noted. Repeat biopsies after gluten challenge showed cellular changes in only two of the eight coeliacs (patients 5 and 6). These occurred at a later stage, 48 and 96 hours respectively, and appeared mainly as increased intracellular vacuolation associated with some signs of cytoxicity, such as more widespread damage of mitochondria and microvilli and excessive extrusion of the absorbing cells (Fig. 2).

The absorbing cells of the two non-coeliac patients appeared normal before gluten challenge. Twentyfour hours after gluten large intracellular vacuoles were seen in patient no. 9 delimited by smooth membranes and containing electron-dense fibrillar material (Fig. 3). Since similar membrane-enclosed material was seen in other fasted patients within minutes after gluten ingestion (personal observations) it was deduced that the vacuoles contained some of the ingested, though altered, gluten retained for an abnormally long period in patient no. 9. The absorbing cells of patient no. 10 also contained similar though smaller vacuoles 28 hours after gluten ingestion but these appeared more like residual bodies. In neither patient were there any signs of increased cell destruction or damage.

\section{The subepithelial connective tissue}

Several of the subepithelial connective tissue structures in intimate contact with either absorbing cells or crypt cells were studied in detail (Table III). These included the basement membranes (basement laminae) of the epithelial and endothelial cells, the endothelium, the fibrous elements, and the infiltrating cells. In the normal mucosa inflammatory cells include plasma cells, lymphocytes and occasional eosinophils and macrophages.

In the initial or pregluten biopsies of six of the eight coeliac patients the endothelium of small blood vessels appeared normal (Fig. 4) but in two, patients 5 and 7, endothelial swelling and an excess of plasma cells were found. In addition many lymphocytes were seen in the lateral spaces between adjacent absorbing cells. Although there was considerable variation in the response of individual mucosae to a challenging dose of gluten, the ultrastructural changes in the connective tissue elements appeared to follow a

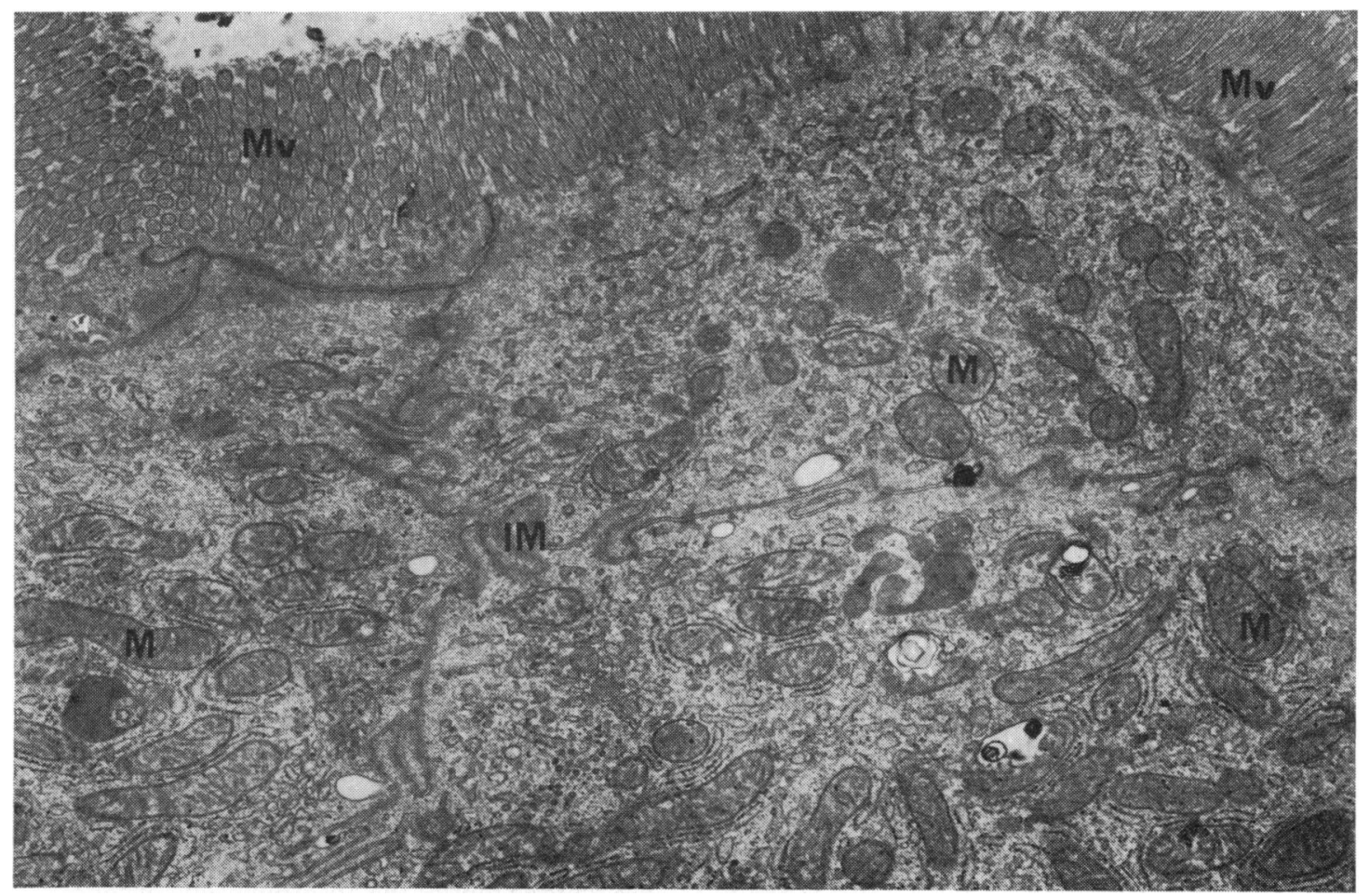

Fig. 1 Oblique section of several normal villous absorbing cells from a pregluten challenge mucosal biopsy. The microvilli (Mv) are seen in vertical section on the right and in oblique section on the left. $\times$ approximately 15000 

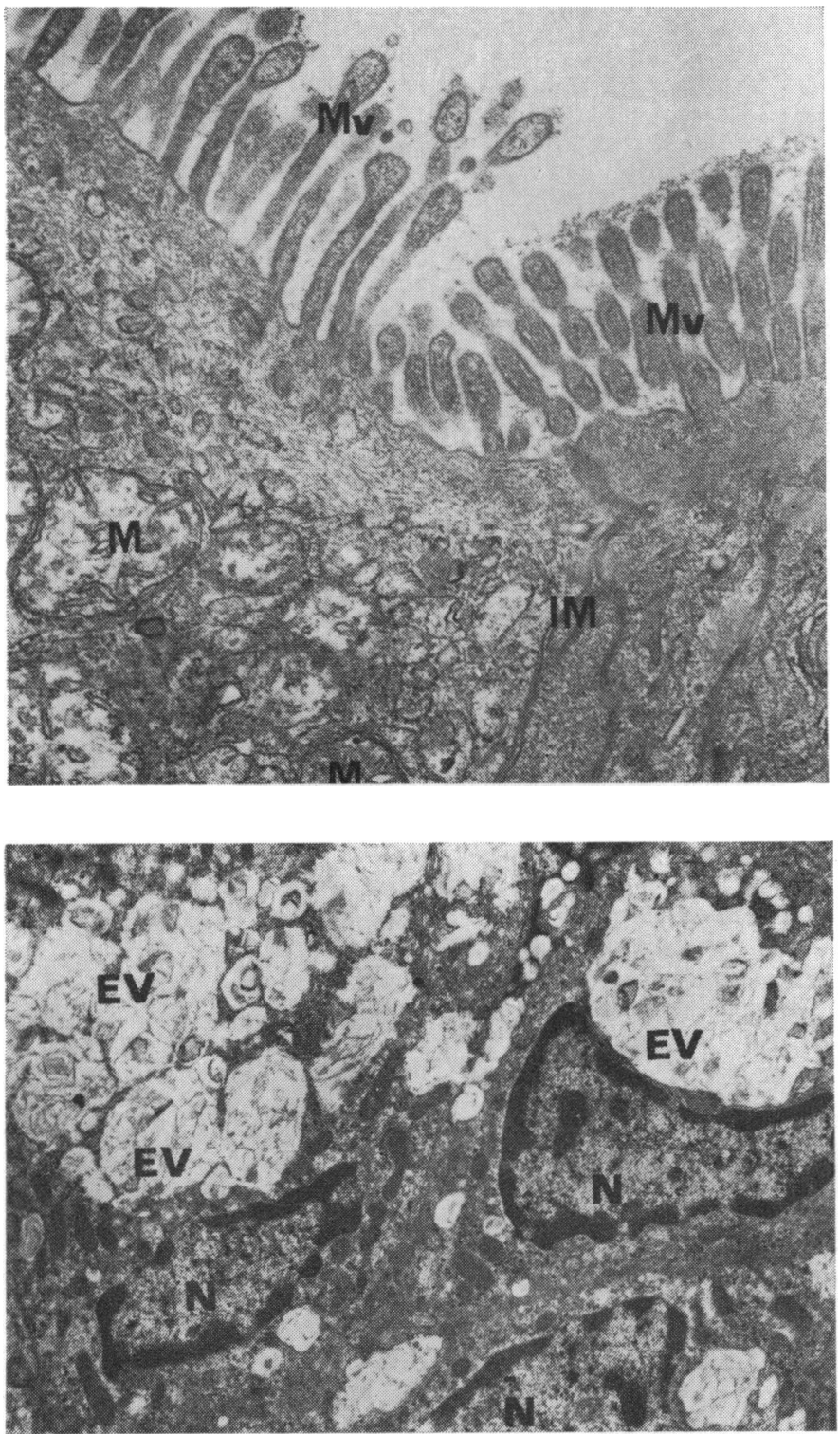

Fig. 2 Section through upper part of two absorbing cells from a mucosal biopsy of patient no. 696 hours after gluten challenge, showing microvillous damage (club-shaped Mv on the left) and swelling of the mitochondria (M). This cell may be compared to the one on the right of the intercellular membrane (IM) which appears normal.

$\times$ approximately 28000
Fig. 3 Supranuclear section through two absorbing cells of patient no. 9 (non-coeliac) 24 hours after gluten challenge. Large confluent vacuoles (EV) containing fibrillar material are seen and appear to indent the nucleus $(\mathrm{N})$. The vacuoles may contain digested material. $\times$ approximately 3500 similar, progressive pathological pattern with time. Nevertheless, there was sufficient difference in the appearances between the well treated and inadequately treated coeliac patients to warrant a separate description of the pathological changes in these two groups.

Inadequately treated patients (nos. 4-8)

Connective tissue changes were not seen as early as two hours after gluten (patient no. 6). Striking changes were, however, observed in this layer at 17 hours after challenge (patient no. 8). There was considerable swelling (cross-sectional increase) of the endothelial cells of the small blood vessels and this often appeared to cause narrowing of the vessel lumen. The endothelial cells (Fig. 5) showed numerous cytoplasmic projections on the luminal side and increased intracytoplasmic vacuoles and pinocytotic vesicles. The appearances therefore suggested hypertrophy as well as swelling. The basement lamina appeared denser and wider than normal and the connective tissue fibrils were moderately in- 


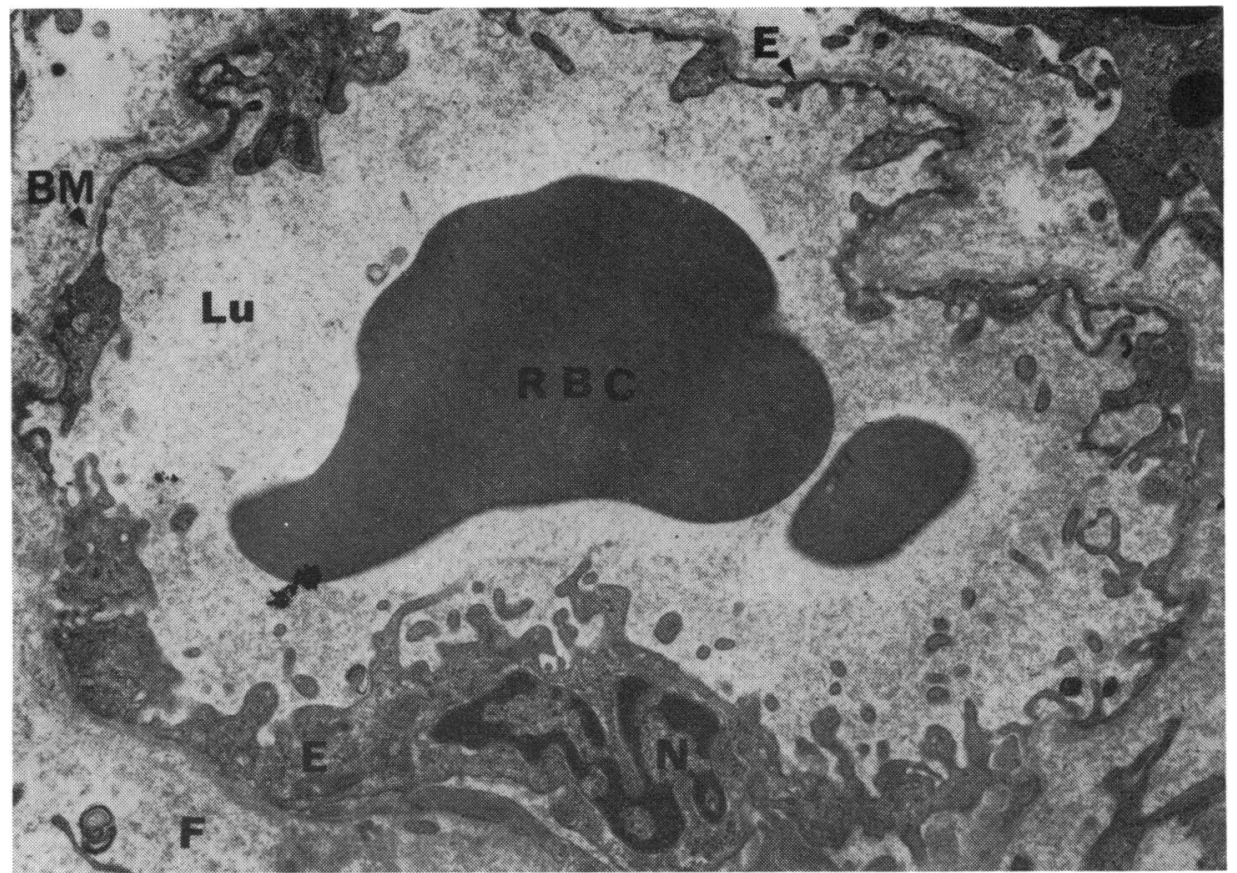

Fig. 4 A small blood vessel lying in the connective tissue immediately below the villous epithelium. From the pregluten mucosal biopsy of one of the well treated coeliac patients. Normal appearances. The endothelial cells lining the blood vessel form for the most part a single layer of flattened cells but more abundant cytoplasm and intracytoplasmic organelles are seen around their nuclei $(\mathrm{N})$. Note the fine layer of tissue fibrils which constitute the basement membrane (BM) of the endothelium. The connective tissue fibrils (F) surrounding the blood vessel are fine and feathery. $\mathrm{E}=$ endothelial cell, $\mathrm{RBC}=$ red blood corpuscle $\times$ approximately 10000

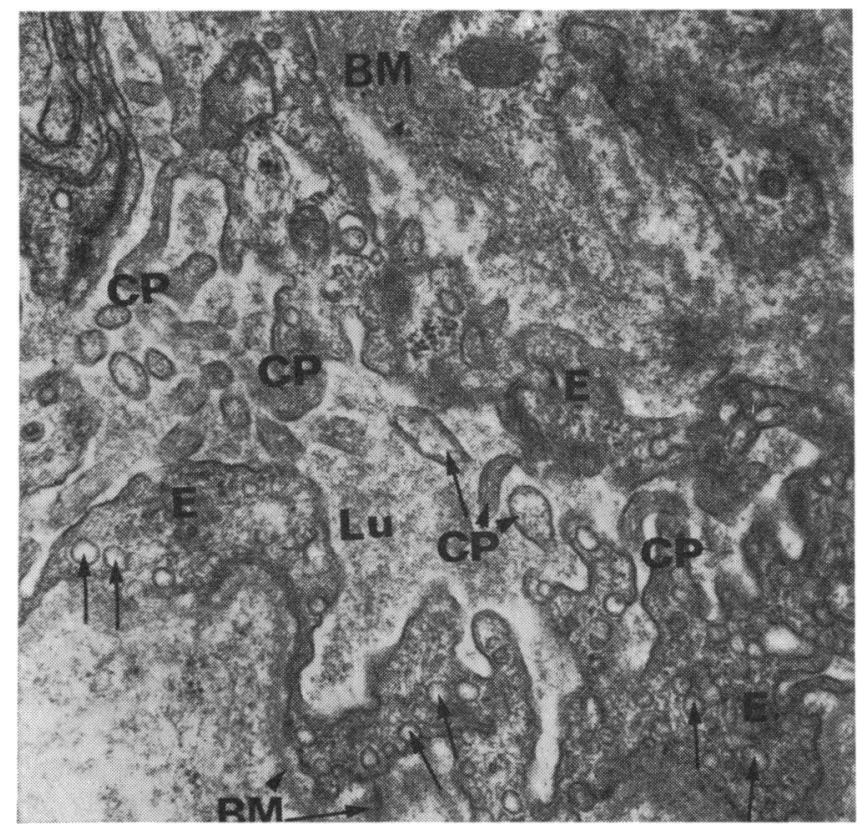

Fig. 5 Part of the endothelial lining of a small blood vessel lying in the subepithelial connective tissue, from a biopsy taken 17 hours after gluten challenge (patient no. 8). Note the swelling of the endothelial cell (E), the increase in pinocytotic vesicles (arrow), and the cytoplasmic processes $(\mathrm{CP})$ extending into the lumen of the blood vessel (Lu). The basement membrane (BM) appears denser and wider than normal. $\times$ approximately 20000 


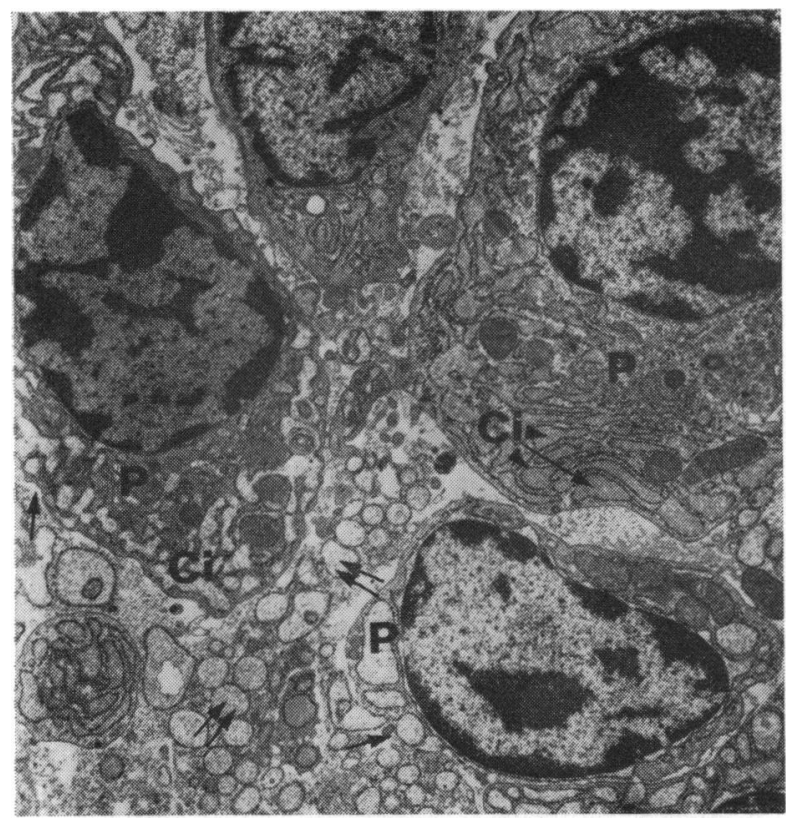

Fig. 6 Several plasma cells $(\mathrm{P})$ in the vicinity of the small blood vessels of the biopsy of patient no. 8. The cisternae $(\mathrm{Ci})$ lined by rough endoplasmic reticulum are dilated and in various stages of activity. The limiting membranes of the plasma cells (arrow) are not always clearly visible and appear to be lysed. Several dilated cisternae appear to be extracellular $(\uparrow \uparrow)$, indicating active lysis of plasma cells. $\times$ approximately 6000

creased. Numerous inflammatory cells were seen in the connective tissue spaces, particularly around the small blood vessels. The predominant cell type appeared to be the plasma cells (Fig. 6) which showed dilated cisternae lined by rough endoplasmic reticulum. In many instances the plasma cells appeared to be lysed since their limiting membrane could not be clearly seen. Since lysis was repeatedly observed in other biopsies after gluten challenge it was deduced that it was probably not an artefact but was the result of enhanced activity of the plasma cells and increased early cell destruction. Numerous lymphocytes and lymphoblasts (see Fig. 7) were also seen, with fewer eosinophils and mast cells. In addition, a few polymorphs (Fig. 8) were observed close to the blood vessels and also in the intercellular spaces of the absorbing epithelium. They were not seen in any of the other patients' biopsies and indeed have seldom been observed in any jejunal mucosal biopsy material studied to date.

Biopsies were obtained from two other inadequately treated coeliacs (patients 4 and 7) 21 to 24 hours after gluten. Endothelial swelling with apparent reduction of luminal patency (Fig. 9) and increased width and density of the endothelial basement membrane was again observed. A mild increase in density and width of the connective tissue spaces and a filling in of these spaces with fibrils was noted. These were either slender, electron-dense, tightly packed structures or were seen as coarser fibres which for technical reasons were usually but not always electron negative. These fibres when electron dense could be identified as collagen and at high magnification displayed their typical regular cross periodicity (as in Fig. 10). Numerous lymphocytes, plasma cells, and fewer eosinophils and mast cells were also present, particularly around the small blood vessels.

In another two patients (5 and 6) postgluten biopsies were obtained at 48 hours. The endothelium, though still abnormal and containing numerous pinocytotic vesicles, appeared less swollen and showed fewer cytoplasmic luminal projections than were seen in the other patients 17 to 24 hours after gluten. The connective tissue fibrils appeared to be increased. The predominant mononuclear cell type was the lymphocyte but in patient no. 6 plasma cells were also seen in large numbers. An interesting observation in patient no. 5 was the almost complete disappearance of fairly active plasma cells seen predominantly in the pregluten biopsy and their replacement with lymphocytes 48 hours after gluten.

Another repeat biopsy 96 hours after gluten challenge in patient no. 6 showed widening of the connective tissue spaces densely filled with collagen fibres (Fig. 10) and numerous active plasma cells. As already noted, widespread epithelial cell damage, specifically affecting the absorbing cells, was observed.

\section{Well treated patients (nos. 1-3)}

Of the three well treated coeliacs two, patients 1 and 2 , had postgluten biopsies after two hours. No pathological changes were noted in the subepithelial layers. Patient no. 3 had a repeat biopsy five hours after gluten. Marked widening of the subepithelial connective tissue spaces with separation of the connective tissue fibrils was observed. The homogeneous background of these spaces suggested oedema. There was separation of the lateral cell membranes of the villous absorbing cells, particularly in the lower half, so that intercellular spaces were created (Fig. 11). These spaces were infiltrated by eosinophils and lymphocytes. The endothelium of small blood vessels remained normal and fibrous tissue increase was not prominent. Further repeat biopsies, however, showed a progressive change in the subepithelial layer of all three patients. More marked deposition of fibrils and the appearance of collagen fibres were seen in the biopsies of patients 


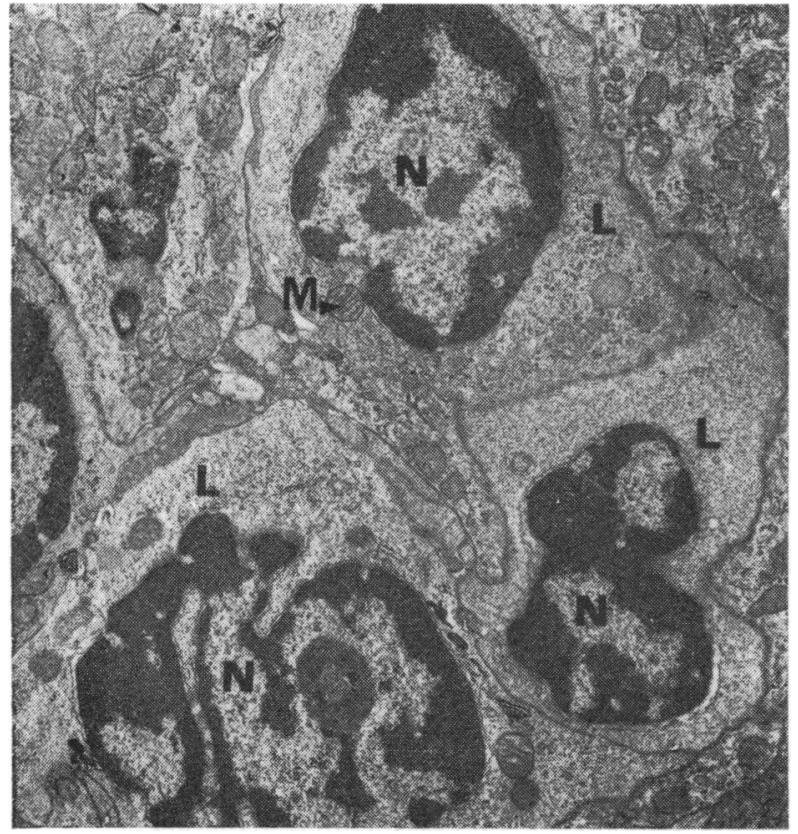

Fig. 7

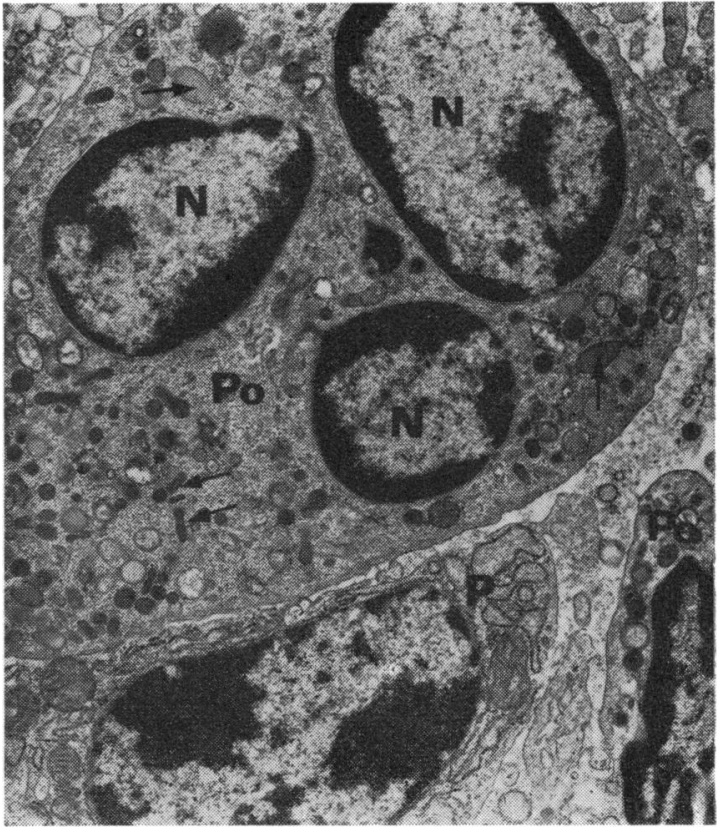

Fig. 8

Fig. 7 Young lymphocytes (L) in the connective tissue spaces of the same biopsy as Figure 6. Their cytoplasm contains numerous free lying ribosomes and scanty membranes of the endoplasmic reticulum. Few mitochondria (M) are seen. $\times$ approximately 7500

Fig. 8 A polymorphonuclear cell (Po) in the connective tissue spaces of the same biopsy as Figure 6. A possible second polymorph is seen in the lower part of the micrograph. These cells are identified by their multilobular nuclei, the characteristic arrangement of the chromatin material close to the nuclear membrane and the presence of heterogeneous granules in the cytoplasm (arrow). A plasma cell (P) is seen in the lower left corner. $\times$ approximately 10000

1 and 2 , progressively increasing from 50 to 98 hours. Early endothelial swelling was noted at 24 hours but this was mild compared to that at 50 to 98 hours. These latter changes were similar to those seen in the inadequately treated patients. A progressive increase in lymphocytes and plasma cells was seen in the postgluten biopsies of all these patients but in patient no. 1 lymphocytes predominated at 50 hours and plasma cells at 98 hours. Eosinophils were seen in all postgluten biopsies but were most numerous at five hours.

No abnormalities were seen in the subepithelial connective tissue, the endothelium of small blood vessels, or the type or extent of inflammatory cells in the two non-coeliac children 24 and 28 hours after oral gluten.

\section{Discussion}

As reported in our previous communication, the dissecting and light microscopic appearances of the jejunal mucosa do not provide detailed information on the effect of gluten on the mucosa. By comparison the sequence of fine structural changes observed at the electron microscope level has provided information which bears on an immunopathological interpretation of coeliac disease.

The morphological changes in the villous epithelium and the subepithelial layers occurring in response to gluten challenge probably depend on the effectiveness of prior gluten elimination from the diet as part of the treatment. Thus the mucosa of well treated coeliac patients may respond differently to a challenging dose of gluten than that of inadequately treated patients. The duration of treatment is probably also an important factor.

In the three well treated patients the ultrastructure of the absorbing cells was not altered up to 96 hours after gluten challenge but in two of the five inadequately treated patients these cells showed excessive extrusion and other signs of cell destruction, such as increased intracytoplasmic vacuolation, as early as 


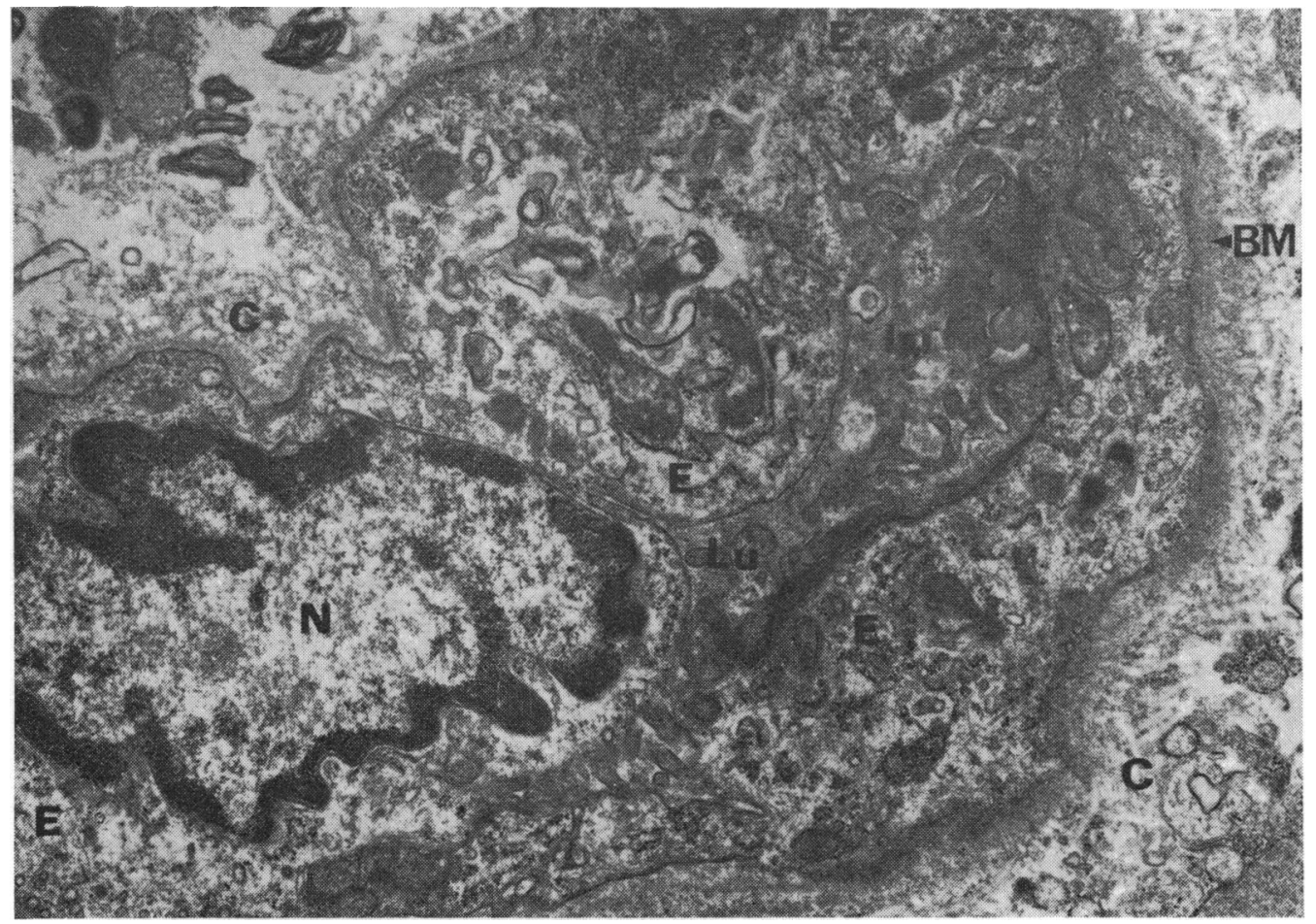

Fig. 9 A small blood vessel lying in the subepithelial connective tissue of a biopsy from patient no. 4, 21 hours after gluten challenge. Note the concentric swelling of the endothelium (E) which appears to obliterate the vascular lumen (lu). The nucleus $(\mathrm{N})$ of one of the endothelial cells is visible. The periendothelial basement membrane (BM) is denser and wider than normal. Some of the connective tissue fibres surrounding the blood vessel are electron negative $(\mathrm{C})$ and may be collagen fibres. $\times$ approximately 15000

48 hours after gluten. However, in these two patients the epithelium was abnormal before gluten challenge, and inflammatory cells, particularly plasma cells, were prominent. Although the present study did not extend beyond 98 hours, it is known from light microscopic investigations (Jos, Rey, and Frézal, 1969) that absorbing cell changes are evident five days after gluten challenge even in well treated patients and are marked by the seventh day. This suggests that in most coeliac patients villous epithelial damage occurs at a late stage and is probably preceded by pathological changes in the supporting structures below the epithelium.

In contrast there were absorbing cell changes in the two non-coeliac patients as early as $\mathbf{2 4}$ and $\mathbf{2 8}$ hours after gluten challenge and these were pronounced in one. The appearances did not suggest cellular damage but rather the engulfment of ingested material in vacuoles limited by smooth membranes. Such vacuoles were not seen in coeliac patients in whom biopsies were performed at similar times after gluten. The significance of this finding is not clear but one of the factors may be the young age of the patient. Other possibilities would include a mechanism, within the absorbing cells of patients not suffering from coeliac disease, for isolating and digesting macromolecular material within the mucosa. This is known in very young animals (Clark, 1959; Rubin, 1966).

In both groups of coeliac patients, connective tissue fibrils were not prominent until 24 hours after gluten intake, but became progressively more marked from 48 to 98 hours. It is of interest that fibrous tissue changes were not seen in the initial biopsies of even the partially treated patients. The widening of the connective tissue spaces, together with the appearance of fine and coarse fibrils, suggests oedema and could be regarded as part of the inflammatory response. Definite changes were also seen in the basement membranes of the epithelium (Fig. 10) and endothelium (Figs. 5 and 9) which appeared wider and denser than normal. All these fibrillar changes could be the result of immunopathological processes. 


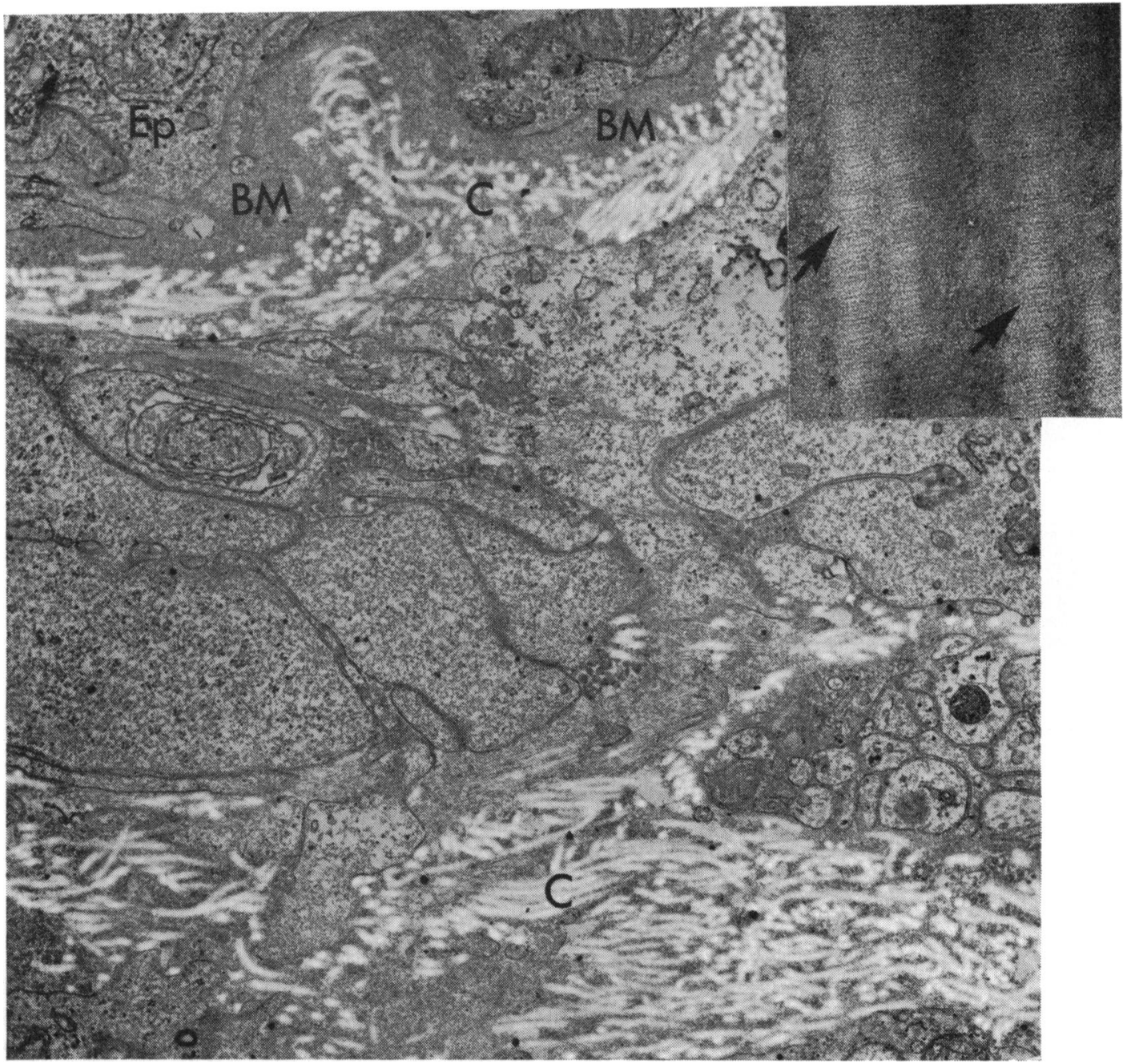

Fig. 10 The subepithelial connective tissue spaces from a biopsy of patient no. 6, 96 hours after gluten challenge. Note the dense basement membrane (BM) of an epithelial cell (Ep) at the top of the micrograph. The spaces are filled with coarse electron-negative fibres (C) presumed to be collagen. $\times$ approximately 22500

Inset shows collagen fibres (arrow) from same biopsy fixed in osmium tetroxide only. These fibres show the characteristic cross-striations of collagen. $\times$ approximately 120000

Some of the most notable changes occurred in the endothelium of small blood vessels in close proximity to the absorbing cells. Marked swelling and hypertrophy of the endothelial cells was seen 17-24 hours after gluten challenge but also at later stages, and appeared to narrow the lumen of blood vessels. The appearances were similar to those reported in and around the glomerular endothelium of the kidney in poststreptococcal glomerulonephritis where they are ascribed to deposition of immune complexes (Michael, Drummond, Good, and Vernier, 1966;
Dixon, 1968). Endothelial proliferation with narrowing of the lumen of vessels has been reported in untreated adult idiopathic steatorrhoea (Shiner, 1970) and could be the end result of progressive vascular damage caused by immunological reactions in and around the blood vessel.

The small bowel is regarded as a lymphoid organ in itself with partly autonomous function (Tomasi, 1968; Watson, 1969). However any mucosal immunological reaction which follows antigenic stimulation could invoke a local as well as a systemic 


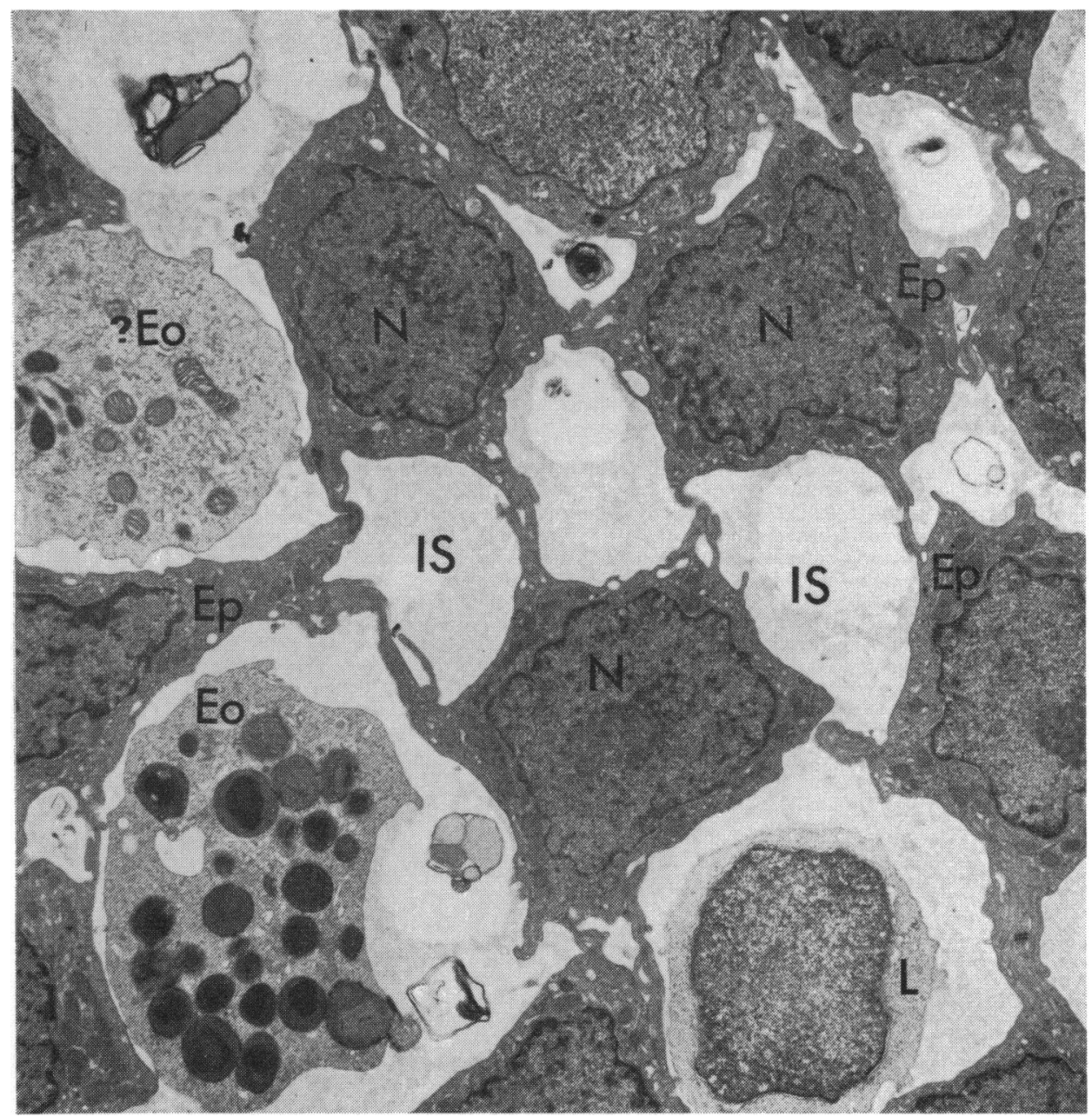

Fig. 11 Cross section through several epithelial cells $(\mathrm{Ep})$ at their nuclear level $(\mathrm{N})$ from a biopsy of patient no. 3, five hours after gluten challenge. The epithelial cells are widely separated. The intercellular spaces (IS) are filled with a homogeneous material, which may be oedema fluid. Infiltration of these spaces with eosinophils (Eo) and lymphocytes (L) has occurred. $\times$ approximately 7500

response. The local responses may be seen in the activity of lymphoblasts, lymphocytes, and plasma cells. The infiltration of the mucosa with polymorphs, eosinophils, and mast cells may be regarded as part of a systemic involvement, and, together with the connective tissue fibrillar changes and the endothelial swelling, suggests an immunological reaction compatible with the Arthus type. (Since the completion of this paper polymorph infiltration has been observed in three out of four patients 11-17 hours after gluten challenge.)

Deposits of immune complexes around the blood vessels have not been identified in this study but tissue immunofluorescence studies designed to demonstrate complexes (Shiner and Ballard, 1972) have shown linear staining in the region of the basement membranes of epithelial cells and blood vessels.

It is noteworthy that in the two non-coeliac patients the subepithelial connective tissue fibrils, the endothelium of small blood vessels, and the type and numbers of infiltrating cells were not affected by the gluten challenge. In these patients there was no morphological change suggesting an immunological response to gluten.

The results of this study therefore show a clear morphological difference in the response to a gluten 
challenge between coeliac and non-coeliac patients. Furthermore it underlines the importance of subepithelial rather than epithelial morphological reactions in the early stages after challenge.

\section{References}

Blecher, T. E., Brzechwa-Ajdukiewicz, A., McCarthy, C. F., and Read, A. E. (1969). Serum immunoglobulins and lymphocyte transformation studies in coeliac disease. Gut, 10, 57-62.

Clark, S. L.,Jr. (1959). The ingestion of proteins and colloidal materials by columnar absorptive cells of the small intestine in suckling rats and mice. J. biophys. biochem. Cytol., 5, 41-50.

Dixon, F. J. (1968). The pathogenesis of glomerulonephritis. Amer. J. Med., 44, 493-498.

Dolly, J. O., and Fottrell, P. F. (1969). Multiple forms of dipeptidases in normal human intestinal mucosa and in mucosa from children with coeliac disease. Clin. chim. Acta, 26, 555-558.

Douglas, A. P., and Booth, C. C. (1970). Digestion of gluten peptides by normal human jejunal mucosa and by mucosa from patients with adult coeliac disease. Clin. Sci., 38, 11-25.

Douglas, A. P., Crabbé, P. A., and Hobbs, J. R. (1970). Immunochemical studies of the serum, intestinal secretions and intestinal mucosa in patients with adult celiac disease and other forms of the celiac syndrome. Gastroenterology, 59, 414-425.

Hobbs, J. R., and Hepner, G. W. (1968). Deficiency of $\gamma \mathrm{M}$-globulin in coeliac disease, Lancet, $1,217-220$.

Jos, J., Rey, J., and Frézal, J. (1969). Effets précoces de la réintroduction du gluten sur la muqueuse intestinale dans la maladie coeliaque en rémission. Arch. franç. Pédiat., 26, 849-859.

Katz, J., Kantor, F. S., and Herskovic, T. (1968). Intestinal antibodies to wheat fractions in celiac disease. Ann. intern. Med., 69, 1149-1153.
Kenrick, K. G., and Walker-Smith, J. A. (1970). Immunoglobulins and dietary protein antibodies in childhood coeliac disease. Gut, 11, 635-640.

Messer, M., Anderson, C. M., and Townley, R. R. W. (1961). Peptidase activity of biopsies of the duodenal mucosa of children with and without coeliac disease. Clin. chim. Acta, 6, 768-775.

Michael, A. F., Jr., Drummond, K. N., Good, R. A., and Vernier, R. L. (1966). Acute poststreptococcal glomerulonephritis: immune deposit disease. J. clin. Invest., 45, 237-248.

Rubin, C. E. (1966). Electron microscopic studies of triglyceride absorption in man. Gastroenterology, 50, 65-77.

Rubin, W., Fauci, A. S., Sleisenger, M. H., and Jeffries, G. H. (1965) Immunofluorescent studies in adult celiac disease. J. clin. Invest., 44, 475-485.

Shiner, M. (1967). Ultrastructure of jejunal surface epithelium in untreated idiopathic steatorrhoea. Brit. med. Bull., 23, 223-225.

Shiner, M. (1970). Mucosal vascular changes in coeliac disease and idiopathic steatorrhoea. Micron, 2, 7-18.

Shiner, M., and Ballard, J. (1972). Antigen-antibody reactions in the jejunal mucosa in childhood coeliac disease after gluten challenge. Lancet, 1, 1202-1205.

Shiner, M., and Shmerling, D. H. (1972). The immunopathology of coeliac disease. Digestion, 5, 69-88.

Shmerling, D. H., and Shiner, M. (1970). The response of the intestina mucosa to the intraduodenal instillation of gluten in patients with coeliac disease during remission. In Coeliac Disease, edited by C. C. Booth and R. H. Dowling, pp. 64-75. Churchill-Livingstone Edinburgh.

Taylor, K. B., Truelove, S. C., and Wright, R. (1964). Serologic reactions to gluten and cow's milk proteins in gastrointestina disease. Gastroenterology, 46, 99-108.

Tomasi, T. B., Jr. (1968). Human immunoglobulin A. New Engl. J. Med., 279, 1327-1330.

Watson, D. W. (1969). Immune responses and the gut. Gastroenterology, 56, 944-965 
am very allergic to flour, would you please make sure that the dishes I have ordered are completely free of flour?' The very practical approach made by the Coeliac Society to help those who have this condition should encourage all doctors to see that their patients become members of the Society, PO Box 181, London, NW2 2QY.

\section{Notes on books}

Clinics in Gastroenterology Vol. 2, no. 1, January 1973: Diseases of the Biliary Tract edited by Ian A. D. Bouchier. (Pp vii +215 ; illustrated. Annual subscription, three consecutive issues, $£ 9 \cdot 00$.) W. B. Saunders, London, Philadelphia, Toronto. 1973. This volume maintains the high level of interest and standards achieved in previous volumes in this series. The book provides a wide spectrum of information on current thinking in biliary tract disease at a physiological, chemical, clinical, and technical level.

Recent Advances in Gastroenterology 2nd edition. Edited by John Badenoch and Bryan N. Brooke. (Pp. ix + 350; illustrated. $£ 6.00$.) Churchill Livingstone, London and Edinburgh. 1972. This edition picks out the important growing points in gastroenterology and each is discussed in depth. The reporting team of 15 members includes Sheila Sherlock (Australia (hepatitis-associated) antigen and virus hepatitis), Iain E. Gillespie (hormones and the alimentary tract), and R. E. O. Williams and B. S. Drasar (alterations in gut bacterial flora in disease). A first class publication.

Nutrition and Its Disorders by Donald S. McLaren. (Pp. v +280 ; illustrated. f1·50.) Churchill Livingstone, Edinburgh and London. 1972. This concise book has been written from the experience gained during 10 years of teaching in a medical school. It covers normal nutrition, primary and secondary nutritional disorders, and nutrition in the community. It has been printed as an inexpensive paperback and will meet an important need in medical education and clinical practice.
Gastric Secretion edited by George Sachs, E. Heinz, and K. J. Ullrich. (Pp. xiii + 452; illustrated. £5.20.) Academic Press, New York and London. This is the proceedings of a symposium on gastric secretion held in Frankfurt in July 1971. It is a multiauthor work on gastric secretion with emphasis on mechanisms at the cellular level. Topics covered are structure, electrical properties, water flow, biochemical properties, enzymology, and stimulus mechanisms of gastric mucosa. Other organs such as pancreas, kidney, and toad bladder are also discussed in the light of acidification mechanisms.

Advances in Proctology edited by $\mathbf{R}$. K. Menda. (Pp. xi + 312; illustrated. Rs. 125.00.) Eastern Medical Books Distributors, Bombay. This volume records the contributions given to an international seminar on diseases of the colon, rectum, and anus held in Bombay in 1968. Amoebae and tubercular diseases are well covered, in addition to the non-malignant and malignant diseases.

Birth Defects. Original Article Series, Part XIII. March 1972, vol. VIII, no. 2, edited by Daniel Bergsma. (Pp. 199; illustrated. £8·50.) Churchill Livingstone, Edinburgh and London. This book is a report of the fourth conference on the clinical delineation of birth defects attacking the gastrointestinal tract, the liver, and the pancreas, held at Baltimore in June 1971. It brings together a remarkable amount of information hitherto widely scattered. Dr Richard McConnell has written the introductory section as well as one of the 28 chapters of this important publication.

The Care of Your Colostomy J. C. Goligher and M. Pollard. Bailliere Tindall, London. 15p. This small, very practical booklet has been brought up to date in the second edition with the practical experience of hundreds of patients who have had a colostomy. It is well illustrated with good line drawings which prove of very great help to patients.

Soothing Food by Ben Duncan (Pp. 180; £2.25.) Faber and Faber, London. 1972. It may not be possible to demonstrate that special diets accelerate the healing of ulcers, but nevertheless patients know that some foods are kinder to their stomachs than others. This book, written by a duodenal ulcer sufferer, will enable others like himself to soothe their stomachs and at the same time enjoy their food. Dr Robert Kemp has written a foreword for this very practical book.

Na-linked Transport of Organic Solutes edited by $\mathrm{E}$. Heinz. (Pp. iv $+201 ; 118$ figures. DM 28.-, US \$ 8.90.) SpringerVerlag, Berlin, Heidelberg, New York. 1972. This records the papers given at a symposium held under the auspices of the International Union of Physiological Sciences in 1971. It brings together presentday knowledge of the coupling between electrolyte and non-electrolyte transport in cells in the intestine, kidney, and pancreas.

Radionuclide Studies of the Gastrointestinal System edited by Leonard M. Freeman and M. Donald Blaufox. (Pp. xiv + 208; illustrated. £6.50, \$13.75.) Grune and Stratton, New York and London. 1973. This book contains the papers included in the 1972 April and July issues of Seminars in Nuclear Medicine which were devoted to the application of radionuclides to gastrointestinal studies.

Speaking at Medical Meetings: A Practical Guide by James Calnan and Andras Barabas. (Pp. ix + 117; illustrated. $£ 1 \cdot 25$.) William Heinemann Medical Books, London. A most practical guide full of invaluable advice. A booklet no one can afford not to have.

\section{Correction}

'Ultrastructural changes suggestive of immune reactions in the jejunal mucosa of coeliac children following gluten challenge', Gut, 14, page 1 , line 18 , the word 'elevated' should have been 'lowered'. 